\title{
From Kythera to Canberra: Vince and Viola Kalokerinos: A migration study
}

JOHN KALOKERINOS 1

The story of Vince and Viola Kalokerinos is, in many ways, typical of the stories of migration from Greece to Australia in the mid-twentieth century. Vince and Viola migrated to Australia for the opportunities it provided and together raised their three children. The café and milk bar they owned and ran became a community hub, serving and strengthening the community that welcomed them. Following Vince's death, Viola's community contributions grew in numerous ways, many far from typical for a migrant woman of her generation.

\section{Kythera}

Valerios Kalokerinos, known in Australia as Vince, was the fourth of five childrenPetros, known as Paul (b. 1933), Maria (b. 1934), Dimitri, known as James or Jim (b. 1936), Valerios (b. 1939) and Kaiti, known as Kathy (b. 1955). ${ }^{2}$ Their parents Ioannis Kalokerinos (1896-1987) and Kyriaki Kalokerinos (née Comino) (19122003), were born in the small village of Alexandrathes in the Kytherian hinterland. Before marrying Kyriaki, Ioannis served in the Greek army for around six years, mostly on Greece's northern border. His experiences, like those of many soldiers who witnessed the horrors of war, stayed with him throughout his life.

Like most inhabitants of the island of Kythera in the early twentieth century (and for many centuries before), Ioannis and Kyriaki were subsistence farmers. They had two bulls and some sheep and they worked their plots of land, harvesting fruits and vegetables and selling or bartering any surplus oil produced by their olive trees. The children all contributed their labour.

\footnotetext{
1 John Kalokerinos is the son of Valerios (Vince) and Viola Kalokerinos and dedicates this essay to them, including on behalf of his brother and sister, Matthew and Kathy.

2 A note on names: many foreign names were anglicised when migrants arrived in Australia because Australians in that era were uncomfortable with unfamiliar or exotic names: H. Gilchrist, 'The Greek Connection in the Nineteenth Century', Canberra Historical Journal 14 (1984): 9. As can be seen, the adopted names often bore little or no resemblance to the original.
} 


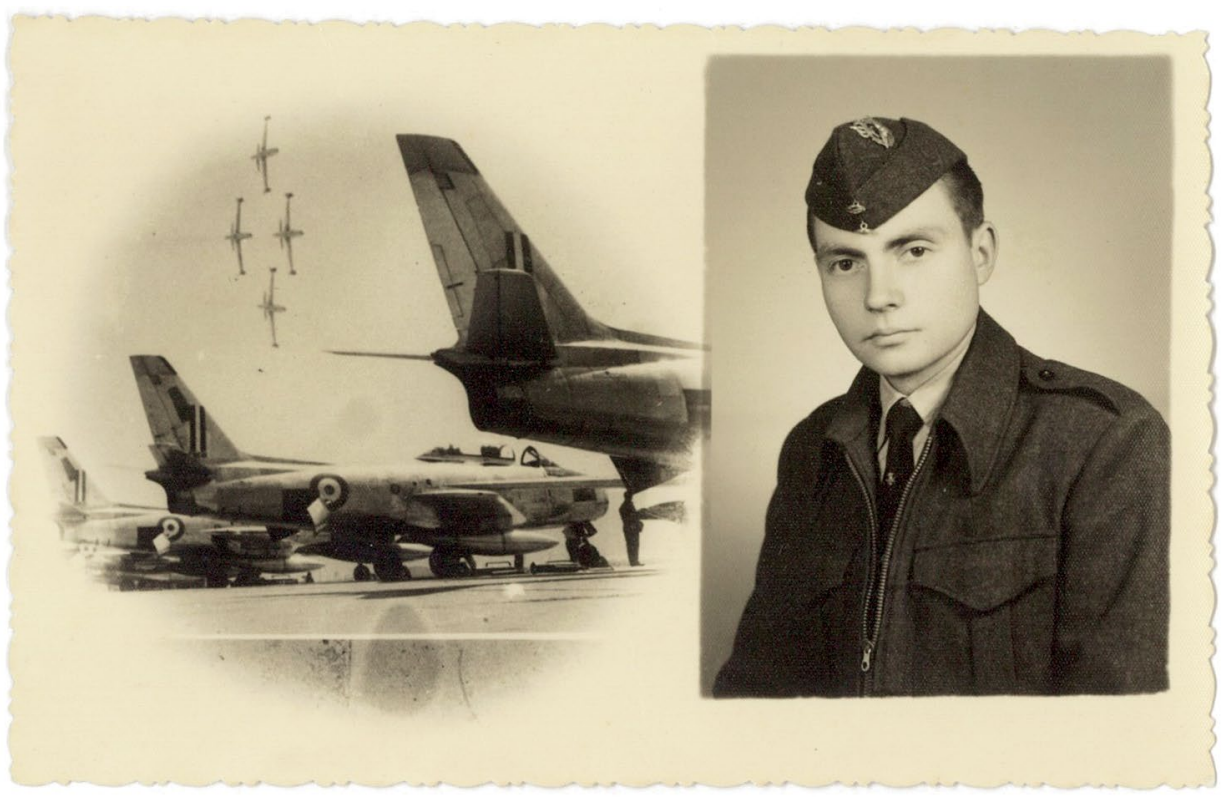

Figure 1: Vince Kalokerinos, Greek airforce service.

Source: Kalokerinos family collection.

Kythera, located to the immediate south of the Peloponnese, forms part of the Ionian island group. It is endowed with a romantic history (it is reputedly the birthplace of Aphrodite, the mythical goddess of beauty and love), and boasts picturesque villages and beautiful beaches. However, like many Greek islands (and unlike mainland Greece), Kythera has limited educational and employment opportunities and is not agriculturally rich. Its inhabitants often fought to make their living through subsistence farming; the rocky and hilly terrain and windswept fields made earning a living from agriculture difficult.

This hardship and lack of opportunity has led to the phenomenon of Kytherian migration. Throughout its history, the island has been a source of net emigration, to the Peloponnese, Crete, Asia Minor, Athens and, later, the United States of America, Australia and elsewhere. Although at times in its history the population has reached around 13,000, such peaks never lasted and its population has remained relatively static at a little over 3,000 since the 1950s.

Kythera (along with Ithaca and the Aegean island of Kastellorizo) was one of the main sources of early Greek migration to Australia from the 1890 s. ${ }^{3}$ In Australia, most Kytherians settled on the east coast of Australia, particularly in small towns and cities across Queensland, New South Wales (including the Australian Capital

3 Hugh Gilchrist, Australians and Greeks, vol. 1, The Early Years (Rushcutters Bay, NSW: Halstead Press, 1992), 10, 78, 190-91; vol. 2, The Middle Years (Rushcutters Bay, NSW: Halstead Press, 1997), 247. 
Territory and region) and Victoria, where the first generation of migrants saw opportunities in small businesses and catering, predominantly in what became the classic Greek cafés and milk bars. ${ }^{4}$ Risson has estimated that the Kytherian-descent population in Australia exceeds 60,000.5

The Australian sons and daughters of the hard-working Kytherian migrants have included many notable figures, across a range of fields of human endeavour. In medicine, Dr Archie Kalokerinos (1927-2012) was a pioneer in the use of vitamin $\mathrm{C}$ to treat Indigenous infant mortality, and the author of several books on topics ranging from Aboriginal health to opal mining. His three brothers also became doctors. In law, the Hon. Theodore Simos (1934-2009), was made a Queens Counsel in 1974 and appointed a Justice of the NSW Supreme Court in 1995. Simos was leading counsel for the British Government in the celebrated 'Spycatcher' case (Attorney-General, United Kingdom v. Heinemann Publishers Australia Pty Ltd [1988] HCA 25). He was opposed in that case by a future prime minister-Malcolm Turnbull. In politics, the Hon. George Souris AM (b. 1949) was a member of the Legislative Assembly of NSW (1988-2015), a minister (1991-95 and 2011-14) and leader of the National Party of NSW (1999-2003); and the Hon. James (Jim) Samios AM MBE (1933-2011) was a member of the Legislative Council of NSW (1984-2003), Parliamentary Secretary (1988-95) and deputy leader of the Liberal Party in the Legislative Council (1995-2003). In academia, Manuel James Aroney AM OBE (1932-2011) was a professor of chemistry at the University of Sydney. He was also a board member of a range of significant public bodies, including the Special Broadcasting Service (SBS) and the Australian Institute of Multicultural Affairs. In philanthropy, Sir Nicholas Laurantus MBE (1890-1980) was the first Greek-born Australian to receive a knighthood. In the arts, George Miller (b. 1945) became a world-renowned film producer, director and writer. His films include the Mad Max series, Lorenzo's Oil, The Witches of Eastwick, Babe and Happy Feet.

\section{Migration to country NSW}

When Valerios was growing up, Alexandrathes had about 20 children and a school. The school has long since closed and there is only a handful of children in the village today. After finishing school, Valerios undertook compulsory military service in the Greek air force and resolved soon after to leave Kythera to pursue the opportunities available in Australia. Following in the footsteps of his brothers

\footnotetext{
4 The Kytherian café phenomenon has been the subject of numerous studies, for example Effy Alexakis and Leonard Janiszewski, Greek Cafes and Milk Bars in Australia (Canberra, ACT: Halstead Press, 2016); Toni Risson, Aphrodite and the Mixed Grill: Greek Cafes in Twentieth Century Australia (Ipswich, Qld: T. Risson, 2007). On the Kytherian presence in Canberra, see Anastasios Myrodis Tamis and Demetrios A. Tsolakis, The History of Greeks of Canberra and Districts (Melbourne: National Centre for Hellenic Studies and Research, 1999).

5 Risson, Aphrodite and the Mixed Grill, 190.
} 
Petros (Paul Calokerinos), ${ }^{6}$ who came to Australia in 1948, and Dimitri (James or Jim Calokerinos), who came to Australia in 1952, Valerios arrived on the Patris on 22 July 1962. 'The vessel, whose name is Greek for 'homeland' or 'mother country', was a large passenger ship that ferried tens of thousands of migrants from Greece to Australia, making a total of 91 voyages between 1959 and $1975 .{ }^{8}$ Most of the migrants during this period were from rural and regional parts of Greece, often from islands.

Eventually all five siblings emigrated to Australia. This was part of a phenomenon denounced in some quarters as a cultural haemorrhage of the Greek nation, but there was arguably little alternative for people seeking greater opportunities than those available in their homeland. ${ }^{9}$ Valerios travelled with his brother Paul, who was returning to Australia from Kythera with his bride Helen (née Petrohilos, who was also Kytherian). Paul was in business in Manilla, in the New England region of NSW, where he operated the York Café and the Canberra Café with his cousin John Travassaros and uncle Bill Summers ('Summers' is an anglicisation of the name Kalokerinos, which is Greek for 'summer' or 'fair weather'). This was a familiar pattern for Kytherian migrants to Australia for much of the twentieth century. As Hugh Gilchrist OAM, the foremost historian of Australian-Greek relations noted, economic, familial and linguistic factors favoured partnerships between shop owners, and particularly family concerns involving brothers, uncles, nephews and cousins. ${ }^{10}$ Paul settled in Manilla and became a respected and much loved presence in the town, remaining in the café trade until his retirement in 2017 at the age of $84 .^{11}$

Upon their arrival in Sydney they were met by relatives of Helen, Charlie (Kosmas) Tzannes and his wife Politimi, who drove them to Tamworth. There they stopped at the Acropolis Café, which was co-owned by Valerios's brother Jim, who was so pleased to see Valerios that he would not let him leave. He immediately set him to work in the café. After some time Valerios left to work for the Kontakos family at the Golden Bell Café, also in Tamworth. But in 1966 Paul and his young daughter Kathy were injured in a car accident and the family pleaded with Valerios to come

6 Some branches of the family adopted the 'C' spelling of the surname.

7 Passenger List, National Archives of Australia, K269, '22 July 1962 Patris'; digital copy accessed 21 April 2018. He disembarked in Sydney on 29 July 1962.

8 Stergos Kastelloriou, 'Remembering the "Patris": The Iconic Ship That Brought Thousands of Greeks to Australia,, SBS Online, updated 19 June 2017, accessed 22 April 2018, www.sbs.com.au/yourlanguage/greek/en/ article/2017/06/14/remembering-patris-iconic-ship-brought-thousands-greeks-australia.

9 Gilchrist Australians and Greeks, 1:214.

10 Gilchrist, Australians and Greeks, 1:191.

11 Paul Calokerinos's story has been told in Sandy Thorn, Old Timers: Magnificent Stories from Mighty Australians (Crows Nest, NSW: Allen \& Unwin, 2011). See also Alexakis and Janiszewski, Greek Cafes and Milk Bars in Australia, 225. 
to Manilla and help Paul at the serendipitously named Canberra Café. ${ }^{12} \mathrm{He}$ duly did so. He worked hard and further learned the café trade, like countless other Kytherians and other Greeks had before him.

Valerios became an Australian citizen in August 1967. Reflecting the difficulty in the Australia of that era of using unfamiliar or exotic names, the name recorded on his citizenship certificate was Vince Summers. Henceforth known in Australia as Vince, he retained the use of Kalokerinos throughout his life. During these early years, when Vince knew little English, much of his work was back of house-cooking for the café, peeling potatoes for chips and related tasks. It was his first time cooking but he learnt on the job, also improving his English by speaking with locals and taking correspondence courses. He lived with Paul's family in rooms behind the café, which were heated with a wood stove. In these years, he took great joy in seeing his nieces Kathy (b. 1963) and Mary (b. 1965) grow up. ${ }^{13}$ He set up a table tennis table in the restaurant and they played in between serving customers. He had relatives and friends (predominantly Kytherians) who owned and worked in cafés in Tamworth and Armidale, and other nearby towns, and he enjoyed catching up with them, exchanging news and stories and playing backgammon. In the little spare time he had, he enjoyed fishing in Lake Keepit, hunting rabbits and ducks for stews, and attending local football matches.

\section{Canberra and the Curtin Milk Bar}

Vince's brother Jim left New England in 1967 and moved to Canberra. He told Vince about the rapid growth the capital was undergoing, and urged him to move there, where he could acquire his own shop. Vince was initially cautious but, after a few years, began to relent. One Thursday in November 1971, he drove down to Canberra and Jim took him to the Curtin Milk Bar, a popular sandwich shop owned by a Greek migrant couple, George and Kaiti Toulkidis, who in turn had purchased the shop from its original owners, the Nikias brothers Bill, Leo and Alex. Vince was initially unimpressed with its location as it was not on the main street, a prize position for cafés in 1960s country Australia. However, it was on a corner location in a thriving shopping centre in a well-located suburb, and he soon realised its potential. ${ }^{14}$ In fact, his conversion was astronomically fast; he purchased the shop on the weekend and by Monday he had started work — so much for due diligence, exchange and settlement! He was to own and manage it for the rest of his life.

12 So named because it was opened in 1927 , the year that the provisional Parliament House in Canberra was officially opened.

13 Paul and Helen later also had a son, John (b. 1975).

14 'Old-Fashioned Values Retained', Canberra Times, 29 September 1991, 9. 
Vince moved in with his brother Jim and sister Maria in Curtin. The shop was a seven-days-a-week enterprise, and he threw himself into it with gusto. Over the course of his ownership, he regularly improved it and saw that it was stocked with the latest chocolates and confectionery. The shop is fondly remembered by former customers for its milkshakes and bags of mixed lollies. In those days, it also sold fruit drinks, cigarettes, tobacco and firecrackers and had popular arcade games. With time, however, all these disappeared. The on-site production of fruit drinks was uneconomical with the wide availability of mass-produced drinks and juices, while arcade games were superseded by home entertainment systems. Firecrackers were banned, and sales of cigarettes and tobacco became uneconomical due to the number of break-ins generated by stocking them, the decline in smoking and their availability more cheaply through supermarkets.

When the nearby Woden Plaza opened in 1972, trade at the Curtin shops declined and Vince recognised the need to diversify his offerings. Noting that Curtin had no pizza shop, he installed a pizza oven a few years later. It proved a wise decision, as he soon acquired a reputation for the high quality of his pizzas, with customers travelling across Canberra for them. They were distinguished by the features that typified the food offerings of Greek migrants: good quality and substantial quantity, with efficient and friendly service, at a reasonable price.

\section{Viola and marriage}

Viola Kalokerinos (née Torakis) was born in 1953 in the village of Karvounathes on Kythera. She was the first-born child of Mathios (1920-2001) and Chrissoula (Chrysso) Torakis (née Kalligeros) (1924-2015) and was followed by a brother, Petros (1955-87), and a sister, Zografoula (Foula) Coroneos (b. 1960). Her parents were subsistence farmers and her father was also a fisherman. Karvounathes, a village in the centre of Kythera, is scarcely larger than Alexandrathes and is only a little over 20 minutes from it by foot. It was a trip Mathios Torakis made many times, selling fish door-to-door on his donkey. Indeed, one of his customers was the Kalokerinos family of Alexandrathes. In 1975 Vince, following the pattern of many migrants of that generation, returned to Greece to find himself a bride. He did so, all in little over a month. Having met Viola after the church service for Kythera's major religious feast day, 15 August, on 17 August they were engaged and on 27 September they married. Although this seems a short engagement by today's standards, for Vince and Viola it was all the time necessary, given that his family knew hers, and also knew Viola. Vince indeed remembered Viola as a little girl from before he left for Australia. There was a difference between them in age of around 13 years-again, not unusual in Greece at that time. In any case, theirs was a successful partnership of 28 years, cut short only by Vince's death in 2003. 


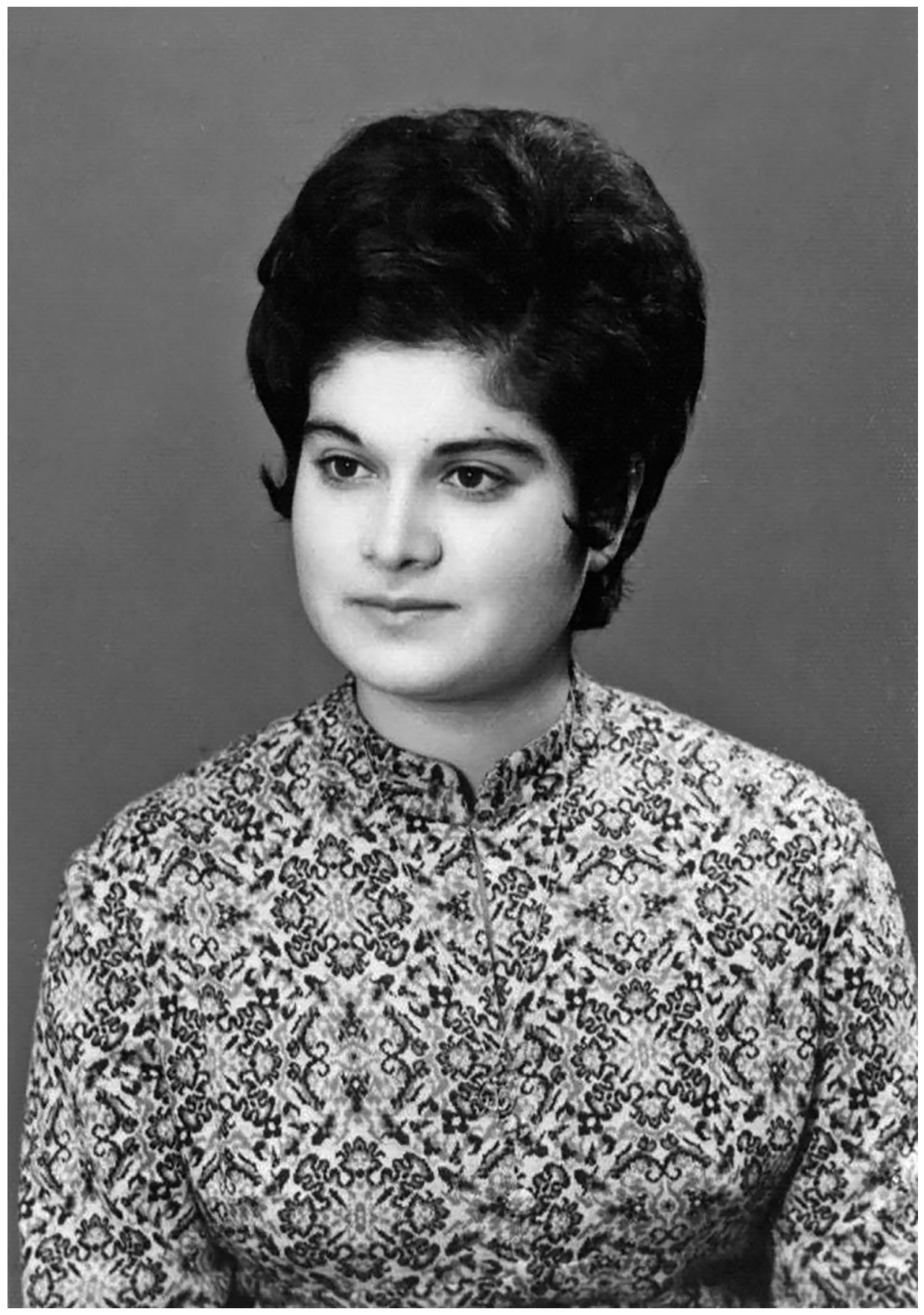

Figure 2: Viola Kalokerinos (née Torakis).

Source: Kalokerinos family collection. 


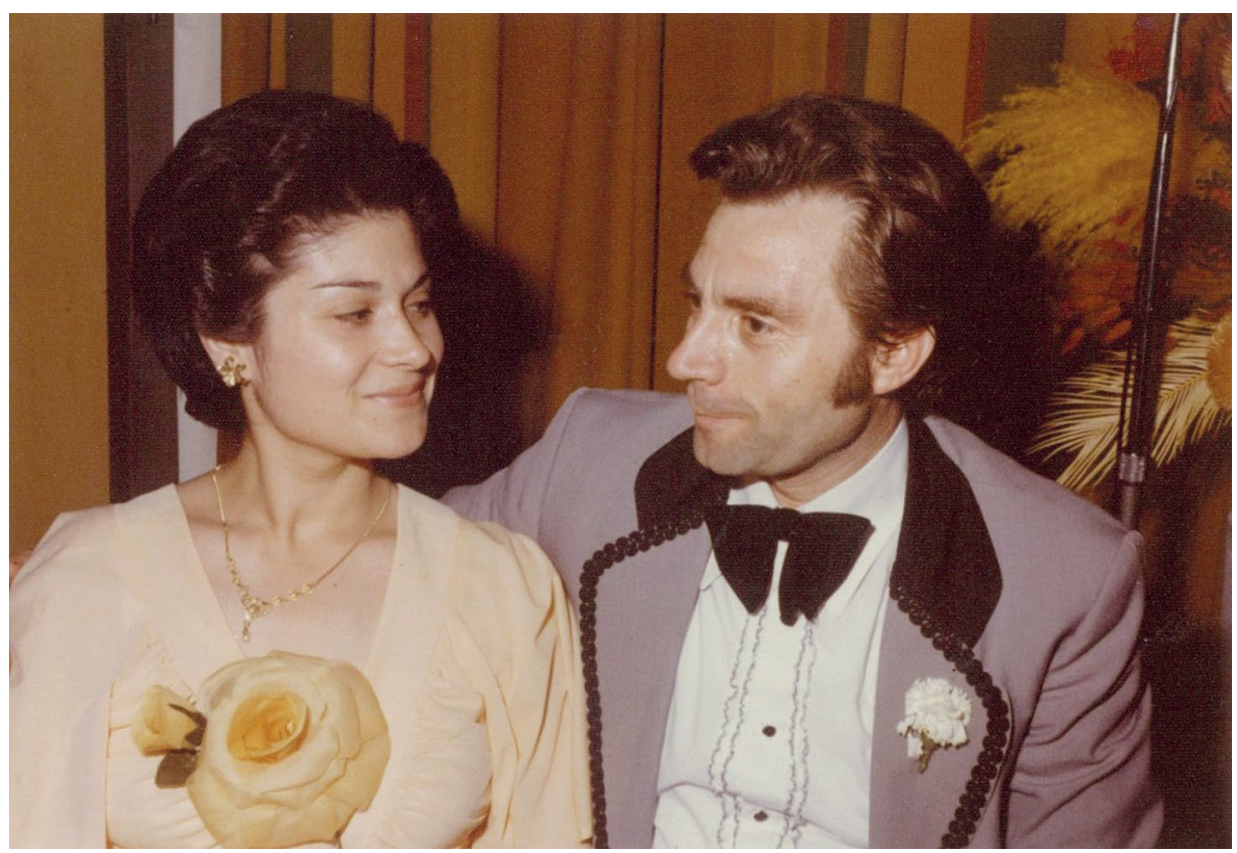

Figure 3: Vince and Viola Kalokerinos, 1977.

Source: Kalokerinos family collection.

Soon after the wedding the couple flew to Australia, arriving in Sydney on 12 December 1975 and driving to Canberra the next day. The date is notable. Viola recalled that a federal election was taking place, memorable for Viola because, after seven years of dictatorship, the distinguished statesman Konstantinos Karamanlis had only recently returned from self-imposed exile in Paris to restore democracy to Greece. The other major impression she had on arriving in Canberra was how small and rural it was compared with Athens, where she had lived and worked for the past few years. ${ }^{15}$ Canberra's population in 1975 was around 200,000, while Athens then had a population of around $2,750,000$. The early years were very challenging for her, but she adjusted quickly to her new home and discovered the wonderful things that her community and her new country offered.

Despite early reservations, she learned to drive, after much prodding by Vince, who explained to Viola that she would not be able to participate fully in community life without driving. Learning English was another early challenge: 'I did not speak one word of the language. I was just 22 and it was very hard'. ${ }^{16}$ In a 2015 oral history interview, she recalled how people wished her a merry Christmas and happy new

15 Viola Kalokerinos, interview by Ann Smith, 26 February 2015, Curtin Living Memories Project, Canberra \& District Historical Society, accessed 28 June 2018, www.canberrahistory.org.au/CurtinLivingMemories/John\%20 and $\% 20$ Viola $\% 20$ Kalokerinos.html.

16 'A Treasure Trove of Memories', Chronicle (Canberra), 6 August 2013, 14. 
year in December 1975, but with her limited English, she had no idea what they were saying. ${ }^{17}$ She learned a little through weekly language classes, but much more from customers and neighbours. The Curtin community was warm towards her and always made her feel welcome. ${ }^{18}$ She became an Australian citizen in August 1979. Being away from her family was something that she accepted early, staying in touch largely through correspondence. In those days, Kythera only had one telephone per village, so telephone contact was impractical. She would not return to Greece until 2009 , a year after selling the shop.

For many years Viola made a range of products for sale in the shop, including kourambiethes (Greek almond shortbread biscuits) and other sweets, such as carrot cake, florentine slice, and lemon and coconut slice. Although she enjoyed much Australian cuisine, she found it very different. Vegemite was immediately a no-go. When she was told about the meat pie, she thought that it would be a local variant of the spinach and cheese pies she knew and loved. Upon breaking one open, she declined to try it and after more than 40 years in Australia, she had still not tasted one. In January 1977, Vince and Viola's first son John was born. A little over five years later the twins Matthew and Kathy arrived. With no family in Canberra and Vince dedicated to the shop, raising the children, particularly twins, was a further challenge for Viola. Typical of the 'café kids' of Greek-Australian cafés and milk bars, all three children worked in the shop, serving customers, washing dishes, stacking shelves and fridges and cleaning floors from when they were old enough to see over the counter, reach the milk-shaker and use the cash register. This exemplified what Gilchrist has referred to as the family basis of self-employment in Greek businesses. ${ }^{19}$

Consistent with traditional migrant family roles, Vince undertook all of the administration and management of the business and Viola played a supporting role. As the years passed, he was increasingly looked up to by fellow shopkeepers in Curtin and his advice and support were sought on local matters. He was well-liked for his easygoing nature and his sometimes cheeky sense of humour. Due largely to the personalities of Vince and Viola, the milk bar increasingly became a community hub, a welcoming place for all generations. Vince and Viola were delighted when it was recognised at the 2001 ACT Business Excellence Awards for its customer service to seniors, and in 2003 Viola was proud when it won the Inclusion in Small Business Award at the ACT Inclusion Awards on the International Day of People with a Disability. ${ }^{20}$ The milk bar came to be regarded as an institution and a local icon, loved by the community. ${ }^{21}$

17 Viola Kalokerinos, Curtin Living Memories Project, 2015.

18 Leonard Janiszewski, interview for In Their Own Image: Greek Australians National Project, 7 July 2002.

19 Gilchrist, Australians and Greeks, 1:215.

20 'And the Winners Are...', Canberra Times, 10 December 2003, 21.

21 Carolyn Brody, Peter Forster and Margitta Acker eds, Curtin Turns 50: The Story of a Canberra Suburb 19642014 (Fyshwick, ACT: The authors, 2016), 134; David Chalker and Barbie Robinson, eds, 100 Views of Canberra (Griffith, ACT: PhotoAccess, 2013). 


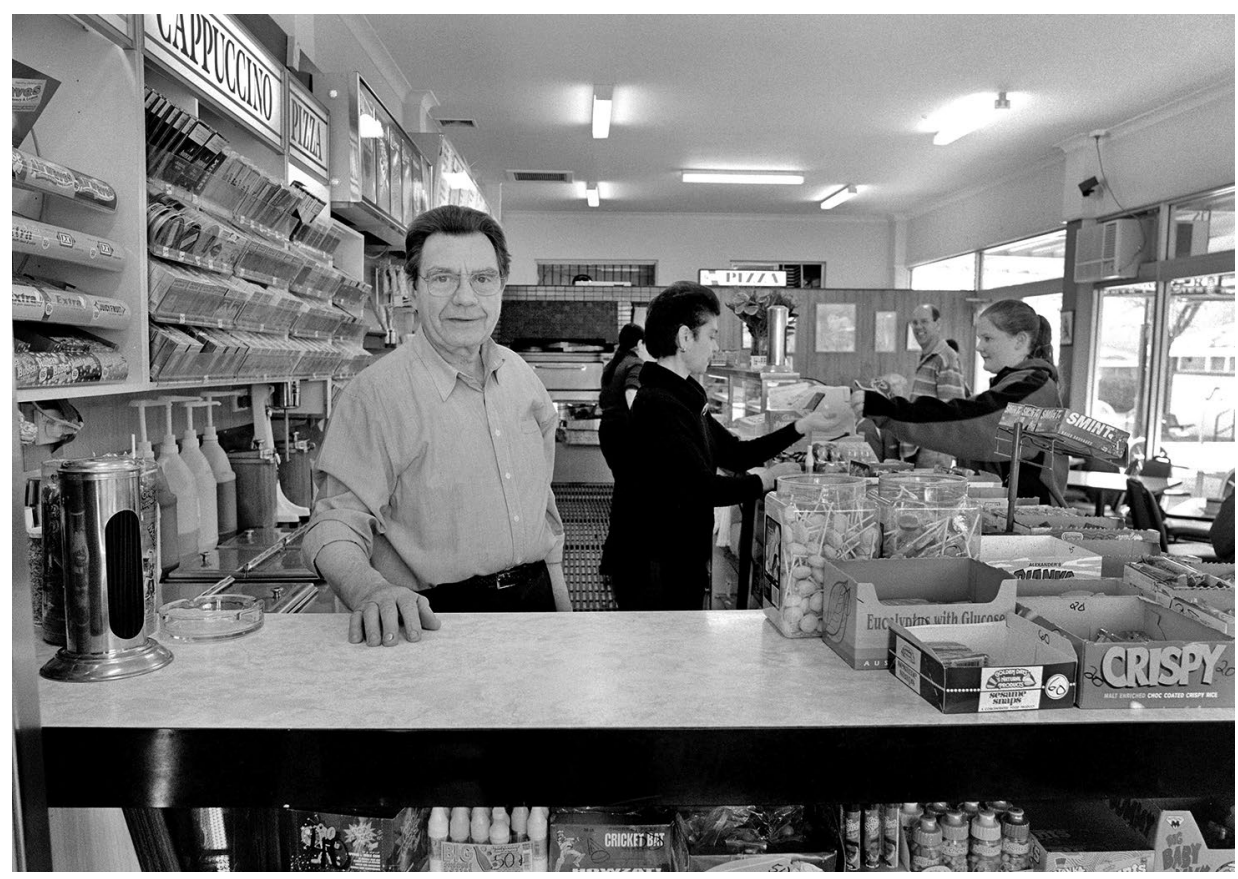

Figure 4: Vince in the milk bar, July 2002.

Source: () Effy Alexakis, photowrite.

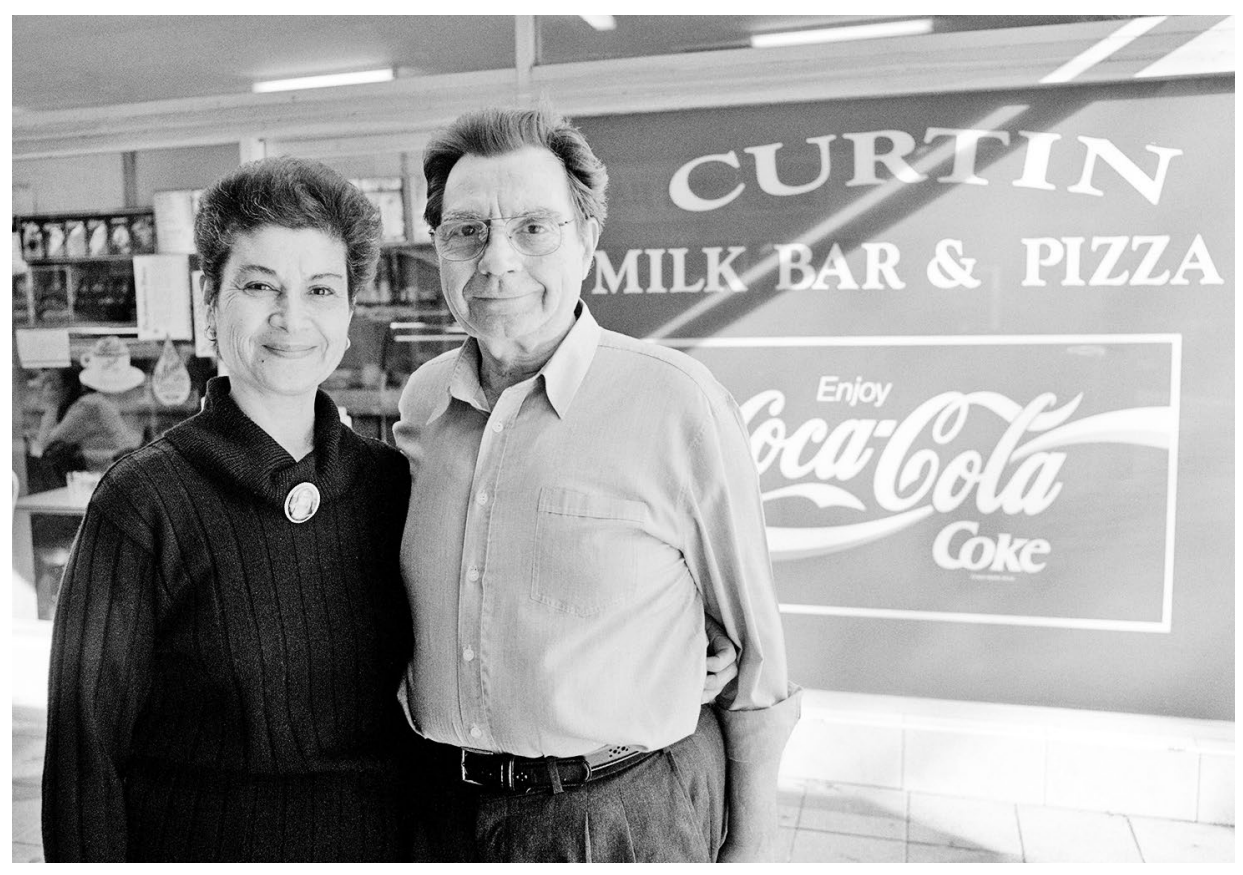

Figure 5: Vince and Viola, outside the milk bar, July 2002.

Source: () Effy Alexakis, photowrite. 
Vince and Viola saw many changes in the community, as the children of the first residents grew up and started their own families. They employed many locals in the shop over the years, and were the first employers of many people who described the experience as a constructive preparation for going onto greater things. In an oral history interview on the occasion of Curtin's 50th anniversary, Kirsten Mann, a former staff member, described Vince as encouraging and supportive, the most popular man in Curtin and a patient and gentle boss. He took an interest in his staff and was pleased when he heard that they had excelled in their studies or their subsequent careers. ${ }^{22}$ Vince and Viola regarded many of the staff as family and maintained friendships with them long after they ceased working in the milk bar.

Being a seven-day-a-week business, opening from early in the morning until $8 \mathrm{pm}$ every night (and 9 pm on Fridays) there was little time for holidays or for getting sick. The only days off were the public holidays at Easter, Christmas and New Year, and these only in the later years: 'Our life wasn't the best because we worked seven days a week. It wasn't very easy ... We didn't have any holidays the first few years -

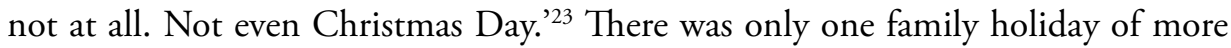
than three days, being a week-long trip to Brisbane and the Gold Coast in December 1989 for the marriage of a cousin. Even this was only possible because Vince's sister and brother-in-law, Kathy and Chris Plumidis, worked with Vince in the shop for a few years after moving from Tamworth. ${ }^{24}$ Vince's relentless long hours and dedication to the shop meant that he had little spare time. He rarely had the opportunity to attend his children's school functions or sporting activities, but he always wanted to hear about them after the event and took pleasure in regaling customers with news of their progress. He and Viola sought to raise the children cognisant of their Greek roots_-speaking Greek at home, eating Greek food, attending Greek school and worshipping in the Greek Orthodox faith. Greek values, particularly the value of education, were important to them both and they were pleased that John, Matthew and Kathy all finished school and graduated from university.

Vince cared about the Curtin community but also about the Greek community. He was a foundation life member of the Hellenic Club of Canberra and a member of the Greek Orthodox Community and Church of Canberra and Districts. He held the view that all Greeks in Canberra should be members of both institutions.

22 Kirsten graduated from The Australian National University and subsequently entered the Australian Public Service. She contributed to the climate change review conducted in 2008 by Professor Ross Garnaut (himself a former customer of the milk bar): Curtin Turns 50 Project, 'Kirsten Mann-Networking at the Curtin Milk Bar', SoundCloud, accessed 28 June 2018, soundcloud.com/curtin-turns-50/kirsten-mann-networking-at-the-curtinmilk-bar.

23 'A Treasure Trove of Memories', Chronicle (Canberra), 14.

24 Vince's younger sister Kathy and her husband Chris Plumidis met in Australia and were married in Tamworth in 1979. They moved to Canberra from Tamworth in 1987 and initially worked at the milk bar, before acquiring their own café, the Liberty Snack Bar, at the Belconnen Markets. They had two sons, James (b. 1980) and John (b. 1983). 
He contributed to the establishment of the Kytherian Brotherhood of Canberra and Districts in the 1980s and was its president from 1989 to 1992, until work commitments prevented him from serving any longer. Viola was similarly limited in the time available to her for community activities but she also regularly attended church and was a volunteer at the Greek-Australian Aged Home in Kingston where Vince's older sister Maria was a resident from 1996 until she passed away in 2015. In 1995 Viola joined the Kytherian Brotherhood committee. ${ }^{25}$ For her, it was a modest first experience of service on a community board. At that time, no one anticipated that much more experience was yet to come.

\section{Vince's death and the final years in the milk bar}

In 2002, in an interview with the eminent cultural historians Leonard Janiszewski and Effy Alexakis, Vince spoke of the predicament of his generation:

Our generation got caught. We had to work for ourselves, then send money to our parents and also support our children — so we really had to work for three generations. ${ }^{26}$

In the same interview he spoke of his plans to retire soon and take a trip to Greece, which he had not visited since 1975. Unfortunately, this was not to be. On 23 August 2003, he suffered an aortic aneurysm, essentially where the aorta bulges and weakens, causing a leak of blood throughout the body. Once an aortic aneurysm starts to tear, an operation is rarely successful and so it was in Vince's case. He died on the same morning, at the age of 64 . His health had been good, but the many years of exacting and relentless work had taken their toll. There was great sorrow from family, friends, his customers and the community he had served since 1971. The Greek Orthodox church in Kingston overflowed at his funeral. ${ }^{27} \mathrm{He}$ was eulogised in the ACT Legislative Assembly as 'the king of Curtin' in a condolence motion by the Leader of the Opposition, Brendan Smyth MLA (who had been raised in and around Curtin), who commented that 'Vince's story in many ways is the story of migrants to Australia and the story of many Canberrans'. Smyth recalled that several years earlier, when the Curtin shops had undergone refurbishments, the community had arranged for a plaque in the Curtin square, outside the milk bar, to honour Vince's long service to the community. ${ }^{28} \mathrm{He}$ spoke of Vince's generosity to charitable causes and to customers and friends who had faced bereavements or other difficulties, sending trays of sandwiches and cakes. Throughout the speech, Smyth highlighted Vince's strong service ethos and his love of family—not only

25 Tamis and Tsolakis, The History of Greeks of Canberra and Districts, 125.

26 Alexakis and Janiszewski, Greek Cafes and Milk Bars in Australia, 227.

27 ACT Legislative Assembly, Hansard, 2003 Week 9, 3,322-23.

28 '30 Years of Service Honoured', Chronicle (Canberra), 3 April 2001, 5. 
his own family, but also 'his extended family, which probably would be half of the Woden Valley'. ${ }^{29}$ In an interview in 2002, Vince spoke of the long hours and hard work involved in the shop, but said that its best aspect was that it was very social; 'we don't say "Yes please", we say "Hi Joe or George, how've you been?". ${ }^{30}$

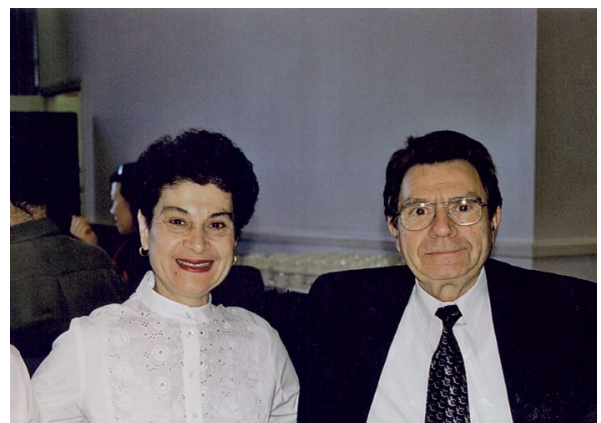

Figure 6: Vince and Viola, 2003.

Source: Kalokerinos family collection.

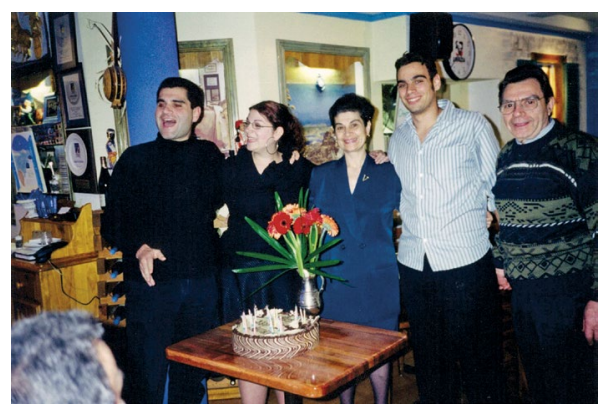

Figure 7: The Kalokerinos twins' 21st birthday; from left John, Kathy, Viola, Matthew, Vince.

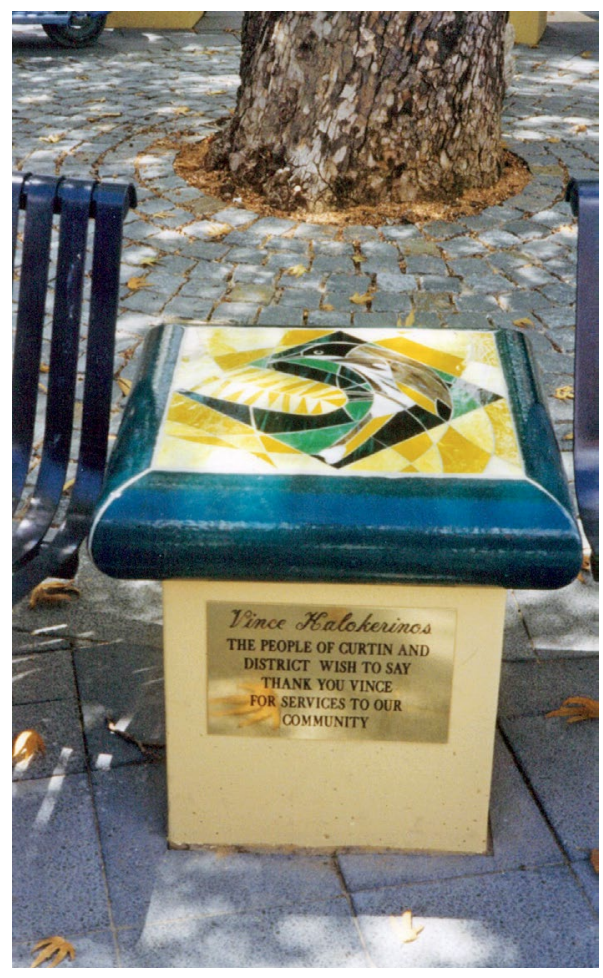

Figure 8: Community plaque to honour Vince's community contribution.

Source: Kalokerinos family collection.

Source: Kalokerinos family collection.

There had been no warning of any health problems. Accordingly, Vince's death was a shock for which Viola and the family were quite unprepared. Viola was left with a dilemma: what to do about the shop? Given that Vince had managed the business, she did not feel confident about taking it over, and felt that the only option would be to sell the shop and retire, even though she was only 50 . Friends and customers suggested that she sell up and take on a lighter workload. After a few months, however, she took counsel from some old family friends who suggested that she was

29 ACT Legislative Assembly, Hansard, 2003 Week 9, 3,219-20. Helen Cross MLA also delivered a tribute, referring to Vince as a friend to thousands of people and to his generosity, kindness, tact and big heart: ACT Legislative Assembly, Hansard, 2003 Week 9, 3,322-23.

30 Janiszewski, interview for In Their Own Image. 
capable of continuing, and she resolved to do so. The staff rallied, and all three of the children took on additional responsibilities, particularly Matthew, who reduced his university study load in order to work in the shop full time. Fortuitously, Vince's brother Jim, who had lived in Kythera for many years caring for their aged parents, had only recently returned after their mother passed away earlier in 2003 . He made an enormous contribution to the running of the shop in the years after Vince's death.

Managing the shop was an exhausting commitment, but Viola felt that her raising had prepared her for it. On the occasion of a symposium to mark the 60th anniversary of the Canberra \& District Historical Society, she reflected:

I am tough ... I grew up on a small island and I was always helping my parents because they were farmers so I was involved from when I was a little girl. It was a great thing for me because that made me stronger and able to cope with a lot of things in life. ${ }^{31}$

Although managing the shop in these years was unrelenting and exhausting for Viola, it was also therapeutic; it kept her engaged with the broader community and helped keep Vince's memory alive. Viola managed the shop for a further five years and only sold it in June 2008, by which time all three children had completed their tertiary studies and entered the workforce in their chosen areas of the law, government and teaching. ${ }^{32}$ Among the encomia congratulating Viola upon her retirement was a hand-delivered letter from the ACT Chief Minister Jon Stanhope AO, MLA. Although he lived on the other side of Canberra, Stanhope had been a periodic visitor to the milk bar, finding it a good place to read or work through his papers over a coffee. In his letter, he wrote:

I have been informed that you have chosen to sell the Curtin Milk Bar after dedicating the majority of your life to its customers. I am aware that you, and your late husband Vince, were greatly admired and that your happy dispositions will be one of the qualities that will be remembered and cherished by your loyal customers ... I am sure that your absence will be greatly felt within the Curtin community. ${ }^{33}$

\section{Viola and the community}

After retiring from the shop Viola became increasingly involved in the community. She felt a strong need to give back to many of the groups and individuals who undertook worthy community work and which had supported her family's business

31 'A Treasure Trove of Memories', Chronicle (Canberra), 14.

32 'Milk Bar Matriarch Hands Over Curtin Keys', Canberra Times, 6 July 2008, 3. The milk bar changed hands a few more times over the next decade. In late 2017 it closed, with the building in which it was housed slated for demolition and redevelopment.

33 Jon Stanhope AO to Viola Kalokerinos, June 2008, private collection. 
and she 'walked the talk' in her commitment. She supported the local schools and churches in their donation drives, joined the Woden Rotary Club and volunteered with Palliative Care ACT and with the Greek-Australian Home for the Aged in Kingston. Joining L'Arche Genesaret, a charity that provides services to people with a disability through supported living, she cooked meals at her home once a month for the members based in and near Curtin. For many members of the L'Arche community, the milk bar had been a sanctuary, and a coffee and a cake there was a regular treat for many members of the community and an important part of their social life. Vince and Viola had ensured the shop was open every day of the week including Sundays, to ensure its availability before and after church, often for limited return.

In 2010 Viola joined a steering committee and rallied community support for the establishment of a community branch of the Bendigo Bank in Curtin. ${ }^{34}$ It was a cause she felt strongly about; Vince had, some years earlier, lobbied to stave off the closure of the Curtin branches of the Commonwealth and Westpac banks, and felt it was particularly important to have a local banking facility for shopkeepers and for the aged in the community. Following a two-year campaign with much intensive community activity by Viola, Bendigo Bank opened its Curtin branch in June $2012 .{ }^{35}$

Viola also supported the Canberra Mothercraft Society, which managed the Queen Elizabeth II Family Centre (QEII) and provided postnatal and early childhood health and social services to families in the Australian Capital Territory and region since 1926. ${ }^{36}$ The centre moved to Curtin in 1997 and Viola joined its board in 2009 , serving in a range of executive positions and as its president from 2015 to 2017. The chief executive officer of QEII, Mary Kirk AM RN, reflected on Viola's contribution, in particular her honesty and leadership by example, and her strength in getting the right people together to forge strategic alliances and common understandings, often literally around her kitchen table. ${ }^{37}$

In 2012 Viola was appointed by the ACT Government as deputy chair of its Ministerial Advisory Council on Ageing, serving until 2017. ${ }^{38}$ This reflected her concern for improving the quality of life of older people. ${ }^{39}$ Over time, Viola developed greater support for women in leadership positions and as role models. In 2018, she joined the Executive Committee of the ACT Division of the National Council of Women.

34 'Push for Curtin Community Bank', Chronicle (Canberra), 20 April 2010, 1.

35 'Curtin Banking on Itself for Service', Canberra Times, 8 June 2012.

36 '90 Years of the Canberra Mothercraft Society Caring for Babies and Their Parents', Canberra Times,

11 November 2016.

37 Correspondence with author, 2 August 2018.

38 'Ministerial Advisory Council on Ageing', Canberra Times, 13 March 2012.

39 'Older Migrants Should “Get More Involved”, Canberra Times, 29 June 2011. 
Viola's community service was acknowledged in a number of forums; an extraordinary feat for a woman who had migrated to Australia from Greece with only college-level education, limited English and relatively limited means. In 2013, to commemorate Canberra's 100th birthday, the federal Member for Canberra, Gai Brodtmann MP, named Viola among 100 women honoured by UN Women for their contributions to Canberra. ${ }^{40}$ In 2015 she was nominated by the ACT in the Local Hero category of the National Australia Day Australian of the Year Awards. Following her nomination, she explained her motivations:

I don't like wasting my time ... I believe we must all get involved with each other. I don't feel I'm a hero but I try to help as much as I can. When I lost my husband ... the community helped me go on with my life. ${ }^{41}$

Viola's service was honoured in a variety of other ways, including being named 'Lady of the Lake' at the 2008 Woden Valley Community Festival and being crowned 'Queen of Curtin'. ${ }^{42}$ She also had her image reproduced as part of a public mural depicting people who have contributed to the well-being of the Woden community. ${ }^{43}$ It was her drive to improve her community and the people around her that inspired her activity. In a 2014 interview, she stated:

If you can make a little difference in their life I think it's very, very important and I am very happy to do that. If someone now needs help, I am happier to spend the time for them than spend it for myself and relax. If I don't do something like that then at the end of the day I don't feel happy. ${ }^{44}$

Clearly, Vince and Viola's joy was in serving the community, not merely food service. Their journey is in many ways both a typical and yet unique version of the migration that has made modern Australia. They both felt privileged to live in Australia — and their community in Canberra in particular — and felt an obligation to give back to it.

\footnotetext{
40 Parliament of Australia House of Representatives, Hansard, 21 March 2013, 3,032.

41 'Viola Volunteers for 16 Community Groups: Australian of the Year Awards 2015', SBS News online, accessed 27 May 2018, www.sbs.com.au/news/viola-volunteers-for-16-community-groups-australian-of-the-yearawards-2015.

42 These ideas were the brainchild of legendary showbusiness publicist and long-time Curtin resident Coralie Wood OAM. The 'coronation' occurred at the December 2016 launch of a history of Curtin: 'Queen of Curtin Crowned as Suburb Celebrates a Book Marking Its 50th Birthday', Canberra Times, 8 December 2016; Helen Musa, 'Lively Tribute to Suburb in Community Book', review of Curtin Turns 50, ed. by Carolyn Brody, Peter Forster and Margitta Acker, City News, 16 December 2016, accessed 27 May 2018, citynews.com.au/2016/reviewlively-tribute-suburb-community-book/.

43 The mural was painted on the wall of Corinna Chambers, adjacent to Melrose Drive, and was commissioned by the Woden Valley Community Council: 'Melrose Drive Mural, Woden', Woden Valley Community Council Inc., 24 April 2018, wvcc.org.au/melrose-drive-mural-woden/.

44 ACT Aged Home Volunteer up for Local Hero', Aged Care insite, 5 November 2014, accessed 27 May 2018, www.agedcareinsite.com.au/2014/11/act-aged-home-volunteer-up-for-local-hero/.
} 
This text is taken from Australian Journal of Biography and History: No. 2, 2019, published 2019 by ANU Press, The Australian National University, Canberra, Australia.

doi.org/10.22459/AJBH.2019.07 